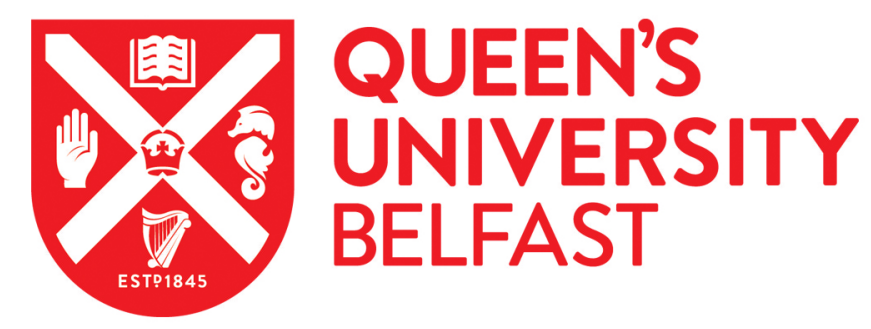

\title{
Lost in Transition? Emerging forms of residential architecture in Kathmandu
}

Sengupta, U., \& Bhattarai Upadhyay, V. (2016). Lost in Transition? Emerging forms of residential architecture in Kathmandu. Cities, 52(March), 94-102. https://doi.org/10.1016/j.cities.2015.11.007

\section{Published in:}

Cities

\section{Document Version:}

Peer reviewed version

Queen's University Belfast - Research Portal:

Link to publication record in Queen's University Belfast Research Portal

\author{
Publisher rights \\ (C) 2015 Elsevier \\ This manuscript version is made available under the CC-BY-NC-ND 4.0 licensehttp://creativecommons.org/licenses/by-nc-nd/4.0/,which \\ permits distribution and reproduction for non-commercial purposes, provided the author and source are cited.
}

\section{General rights}

Copyright for the publications made accessible via the Queen's University Belfast Research Portal is retained by the author(s) and / or other copyright owners and it is a condition of accessing these publications that users recognise and abide by the legal requirements associated with these rights.

Take down policy

The Research Portal is Queen's institutional repository that provides access to Queen's research output. Every effort has been made to ensure that content in the Research Portal does not infringe any person's rights, or applicable UK laws. If you discover content in the Research Portal that you believe breaches copyright or violates any law, please contact openaccess@qub.ac.uk. 


\title{
Lost in Transition? Emerging forms of residential architecture in Kathmandu
}

\author{
Urmi Senguptaa, Vibha Bhattarai Upadhyayb \\ a School of Planning Architecture and Civil Engineering, Queen's University Belfast, UK \\ b Institute for Culture and Society, University of Western Sydney, Australia
}

\section{Introduction}

Kathmandu has been one of the last few cities in the world which retained its medieval urban culture up until twentieth century (Aranha, 1991; Levi, 1992; Tiwari, 2001, Gutschow and Kreutzmann, 2013). Various Hindu and Buddhist religious practices shaped the arrangement of houses, temples, stupas and urban spaces giving the city a distinctive physical form, character and a unique oriental nativeness. Unlike many medieval European cities Kathmandu didn't have an industrial past. Its urban history therefore did not follow Mumford's (1938) three technologically determined eras - the medieval city ("eotechnic age"), the industrial city ("paleotechnic age"), and the future ("biotechnic age"), or "post-industrial" city - that he used to define Western cities. Local historians such as Mahesh Chandra Regmi mark the year 1786 as the beginning of 'modern era' in Nepal when Prithvi Narayan Shah (the first King of Unified Nepal) established Kathmandu as the capital ${ }^{1}$. Regmi approached modernity through the historical analysis of chronological periods of various lengths and history of Royal dynasties that ruled Nepal. With unification the country saw a new form of political and economic governance but their ramifications rarely penetrated the society's rich and illustrious culture for the next 200 years. People continued to work as farmers, artists and craftsmen; and kept their ties with the traditional occupations. The city was physically isolated due to high altitude and surrounding mountains. It remained politically and culturally insulated from both European or Persian sovereignty by resisting Muslim invasion in $15^{\text {th }}$ century and Colonial subjugation in $18^{\text {th }}$ century'. Kathmandu retained its purity and timeless character almost as a frozen city that didn't move, grow or change with time. It thus remained seemingly irresistible to Western scholars who admired the mystic, deep, religious and cultural roots of the city. Much earlier, William Kirkpatrick during his visit in 1793 described Kathmandu valley saying 'there are nearly as many temples as houses and as many idols as inhabitants' (Kirkpatrick, 1811, p.150). According to his estimate, the city had about five thousand houses (Ibid: p.150). Levy (1992), referring to Bhaktapur, an indigenous historic settlement, called it a mesocosm - an essential middle world situated between the individual microcosm and wider universe. Over the years, the clustered historic settlements in Kathmandu with a living urban culture have become a pilgrimage sites for scholars in architecture, planning and history (Gustchow and Kreutzmann, 2013).

The pursuit of modernity in Nepal effectively began with the redevelopment of the entire southern quarters of Juddha Sadak, a prominent street leading to the historic Durbar Square in Kathmandu, as part of the rebuilding in the aftermath of 1934 earthquake. In 1955, Tribhuvan International Airport was inaugurated, opening Kathmandu to the outside world. Simultaneously, the first city plan was prepared in 1969 and Nepal Telecommunication office established in 1975, all of which would further develop in the following decades and become trademark of modernity. Simply put, modernity signifies progress and development implying something

\footnotetext{
${ }^{1}$ The state of Nepal came into existence in the 18th century when Prithivi Narayan Shah, the king from a small state of Gorkha, fought several battles to combine small feudatory states into one, including the Kathmandu Valley which was previously divided into three small kingdoms under the Malla rulers (11th-18th centuries). Prithivi Narayan Shah established Kathmandu as the capital of Nepal.
}

\footnotetext{
2 There have been many attempts of British invasion in Nepal and tales of braveries of Nepalese soldiers. The first attempt wasthe battle at Nalapani in 1814-16, followed by fierce attack in Jaithak met with stubborn resistance eventually forcing British commanders to retreat (See, Northey and Morris, 1928)
} 
different from the language of 'medieval'. The short history of Kathmandu's modernisation suggests the city did not quite follow Mumford's three phases of civilization. It rather moved directly from eotechnic to biotechnic era. Much has changed in the last few decades with city's buildings and spaces going through a rapid change within a compressed timeframe. A confluence of multiple social, economic and cultural forces appear to influence this transition.

The changing urban landscape of the city today is attributed to the material conditions of the $20^{\text {th }}$ century with urbanisation and globalisation emphasizing a 'modern culture' in architecture and lifestyle. High profile palaces and monuments (such as the former palaces Singha Durbār and Narayan Hiti Durbar, Durbar High School, Trichandra College, Clock Tower and numerous courthouses) built under the influence of neoclassical architecture during Rana rule in the last century herald a departure from traditional architecture, which manifests in its extreme form in the new residential architecture. This trend, accelerated by the shift from owner-built housing to developer-built housing has led to creation of new forms, identity, and aesthetics. New residential design is dominated by distinctive patterns of Western suburban ideal comprising pastiche of detached or semidetached homes and high-rise tower blocks. This architectural iconoclasm can be construed as a rather crude, if not cataclysmic response to the indigenous spaces and builtform. Traditionally, private houses were organized around a residential square where people from the extended families resided. Often the votive miniature temple, large water spouts or a well-enhanced aesthetics of the space provided local residents with the opportunity to interact and socialise. The embedded nature of public and private spaces was unique to Nepalese society that accommodated the age old socio-cultural and religious practices. Today, the characteristic feature of this transformation - a sense of rupture and discontinuity - is not only limiting opportunities for social interactions but also eroding traditional housing forms and spatial system. In the historic core, traditional buildings are replaced by incongruous tall buildings with little emphasis on artistic taste (Gustchow and Kreutzmann, 2013; Shrestha, 1981). Elsewhere, the 'free standing' houses erected on subdivided plots of the former palace compounds were branded as 'visual crime'. (Gustchow and Kreutzmann, 2013). Moreover, the recent devastating earthquake of 25 April 2015, which flattened over 600,000 buildings and killed over 8,000 people, further placed the appropriateness of the new residential architecture at the forefront of discussion.

The paper attempts to dismantle the current tension between traditional and contemporary 'culture' (and hence society) and housing (or builtform) in Kathmandu by engaging in a discussion that cuts across space, time and meaning of building. In a deeply traditional city such as Kathmandu, architecture as Mand (2013) contends, has been the primary conduit through which tradition and modern binary is articulated. Kathmandu extols the ingenuity generated by its traditional architecture and has inspired scholars to delve deeper into introspective exploration of its traditions, cultures and nuances to explain the advent of modernity and continuity of change. Our approach is therefore as consonant with those of Gutschow and Kreutzmann (2013), Shrestha (1981), Tiwari,(1991), Shrestha (2010), (Levy, 1992). All of whom are interested in finding roots of emerging architectural forms in Kathmandu in order to establish its identity, place in history and embodied urban change (or lack thereof).

The next section discusses the organisation of space and house types in the traditional and contemporary Kathmandu to illustrate some of the many paradoxes that confront the notion of traditional vs. modernity in architecture. This will be followed by a discussion on shifting boundaries, social identities and the new modernity questioning their ramification in the creation of a modern city. The paper concludes that residential architecture in Kathmandu today stands disoriented and lost in the transition.

\section{Distinct identity to unsettling modernity}

The variegated history of the traditional architecture and builtform of Kathmandu dates back to roughly 2000 years owing to various kings and dynasties (such as Licchavis, Mallas, Ranas and Shahs lately) contributing to city planning. Early history suggests a distinct progression and design in different periods due to the city's transitional location between India and Tibet/China and cultural influence from both sides (Table 1). Building and artistic activities, particularly from the Malla rule of the $15^{\text {th }}$ and $16^{\text {th }}$ centuries - regarded as one of the glorious periods - gave Nepalese architecture and built-form a strong identity. The effects of mutual rivalry of the city kings, artistic development and competitive mercantile economy on the cultural transformation reflected in the 
city's layout, art and architecture. Royal Palaces and Squares assumed the highest importance as administrative, bureaucratic and religious spaces. These were also multifunctional spaces implying an extended involvement of 'Royal' institutions in the society. Whilst the traditional Royal towns exhibit an organic growth over centuries, scholars (Tiwari, 2008; Müller, 1981) argue that they are certainly not unplanned settlements despite absence of wide roads, a common trait of planned settlements. The immediate areas surrounding the Palaces were occupied by the elites, the people from the higher castes ${ }^{3}$. The lower castes lived outside the city walls. Different parts of the city, especially district (tol) were often noted for their socio-economic characteristics due to the predominance of one caste-based stratification such as Nay Tol, Pore Tol and Brahmu Tol manifested in the spatial structure of the city (Shrestha, 1981). These references also imply that the importance of the district- tol declined with distance from the city centre (Wright, 1877).

Table $1 \quad$ Nepalese architecture in chronological order

\begin{tabular}{lll}
\hline Type of homes & \multicolumn{1}{c}{ Period } & \multicolumn{1}{c}{ Attributes } \\
\hline $\begin{array}{l}\text { Early Nepali } \\
\text { home }\end{array}$ & $\begin{array}{l}\text { Pre- Medieval era } \\
\text { (300AD-879AD); } \\
\text { Lichchabi dynasty }\end{array}$ & $\begin{array}{l}\text { Use of stones, decorative motifs showing influences from } \\
\text { Sarnath and Mathura Schools of Gupta architecture in India }\end{array}$ \\
\hline Newari home & $\begin{array}{l}\text { Medieval era (1200AD- } \\
\text { 1769AD); Malla } \\
\text { dynasties }\end{array}$ & $\begin{array}{l}\text { Houses of brick and tile, wit-pitched or pen-roof and } \\
\text { enclosed wooden balconies of open carved work; bricks as } \\
\text { the main structural material and richly carved woodwork; } \\
\text { Tibeto-Burmese influence }\end{array}$ \\
\hline Shah home & 1769AD-1846AD & $\begin{array}{l}\text { Continuation of Malla architecture with influence from } \\
\text { Mughal architecture in India }\end{array}$ \\
\hline Rana home & Rana period (1846AD- & $\begin{array}{l}\text { Neo-classical, Baroque or industrial style with columns of } \\
\text { different orders; French windows and white plaster; a style } \\
\text { much in use in Europe and in neighboring India by the } \\
\text { British }\end{array}$ \\
\hline 1951AD) & $\begin{array}{l}\text { Town houses, row housing, apartments; use of concrete and } \\
\text { bricks, influence of globalization and westernization }\end{array}$ \\
\hline Modern Nepali & 1951AD onwards &
\end{tabular}

The art and architecture that prospered in the three city states 4 in Kathmandu suggest their rulers' passionate involvement in building temples, monuments and public spaces, in art, astronomy and mysticism, all of which would be deeply etched in the lifestyle of the people. The pagoda roofs (diminishing tiered roofing) of the Hindu temples were supported by intricately carved wooden struts and pillars with various legendary figures, animals, Tantric deities and human figures. The Shikhar pattern of architectural temples had five to nine vertical sections forming a rising tower just as though they are depicting the crown of Himalayas. Often the top of the Shikhar is adorned by a highly ornate Pinnacle (Gajur). These temples were not only a part of the urban landscape but also a part of the social and economic life of the valley. The splendour of the Newar town design seems to emanate from an innate sense of aesthetics, a natural rhythmic articulation achieved over a long time span rather than a conscious organisation of space according to dictate" (Slusser, 1982, p. 94).

\section{Newar Houses and spaces}

A typical Newar house was a three to four storied building which either faced the courtyard or the street. While the sides of the houses which faced towards the streets were often used as shops, the inner sides facing the courtyard were used as open areas for living and also as workshops approached through courts (Müller, 1981). The top floor was the kitchen space which also consisted of a separate prayer room or an area was allocated for daily worship of deities. Some houses are even connected at the attic level, which would be opened on the days of large communal feasts (Pant, 2002). Typical building materials were red bricks laid out on mud mortar. Timbers were used for floors, doors, windows and roof structures. The houses had richly carved wooden windows facing the streets. The windows were small to shut out the winter cold. Courtyards were shared spaces

\footnotetext{
${ }^{3}$ Class hierarchy is the stratification of the society largely based on the traditional occupations of the people in the Kathmandu Valley.

${ }^{4}$ Kathmandu valley had three kingdoms, Kathmandu, Bhaktapur and Lalitpur (Patan).
} 
to observe religious or everyday activities. Levy (1992) sees the Newari city as being constructed of successive interlocking cells (household, lineage, neighbourhood and city), each sustained by its culture and its cultural performance. His view subscribes to the notion that space reflects identity that is socially produced. The individual house was thus a part of the larger group which consisted of houses built around courtyards and people generally moved through a series of interconnected courtyards to get to streets and nearby public squares. Each neighbourhood or Tol of around 150-300 houses was intricately linked to people based on their caste and occupation, thereby giving them a unique collective identity. The location of the house in a typical street or in Tol indicated the social status of the owner. Each house was two to three storeyed and accommodated a joint family of parents, their children, and their grandchildren, living together for social as well as economic reasons (Haaland, 1982).
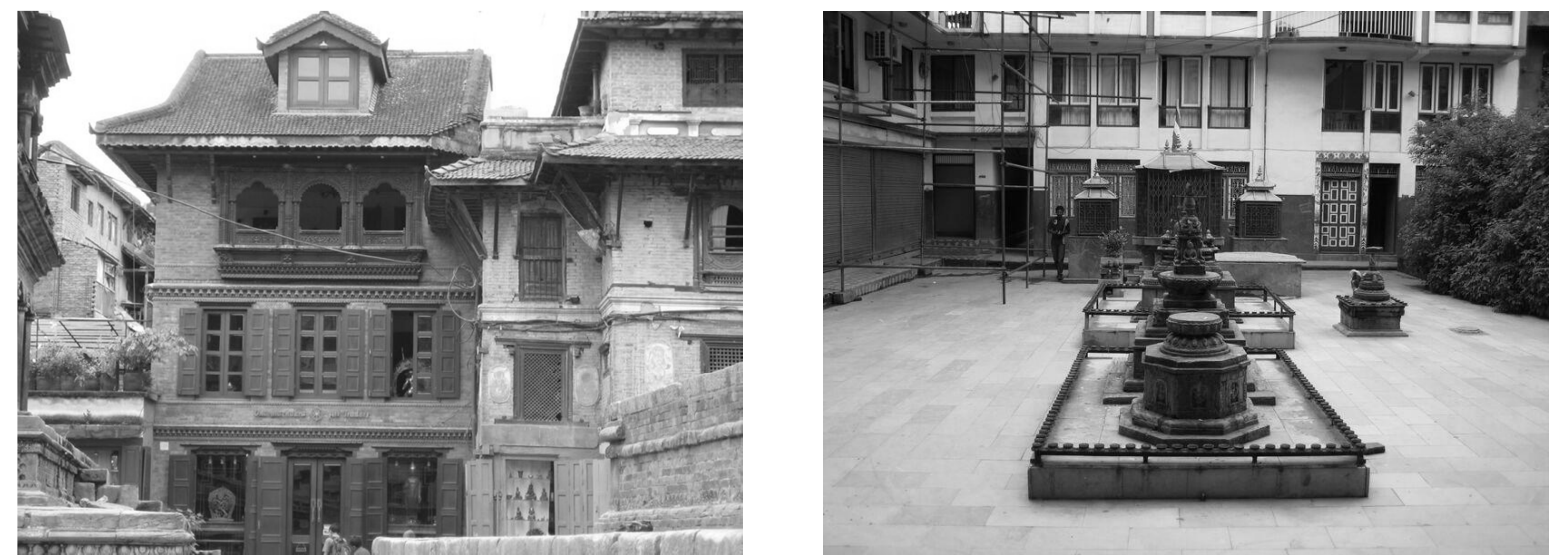

Figure 1: Typical Newari homes set in a courtyard

\section{Source: Authors}

An important element linking history with Nepalese use of space is the socio-religious ritual. An individual's house is the first place of worship, where there is usually a corner or a separate room dedicated to different deities. The doors are low in height believed to be to show respect to your own house when entering it by bowing your head (Haaland, 1982). There is also a place of worship in the courtyard, which is worshipped by the families living around the courtyard. Away from the periphery of the house, at the first junction of the streets, there is a temple, often for Lord Ganesh or Goddesses Bhagavati. In larger open spaces of the locality, bigger temples are found. The distinction between private and public space symbolizes the negotiation of individual and collective identities, articulated and regulated by daily or annual rituals, or festivals. Each family is thus attached to the deities located at different parts of the city. The festivals, attached to certain deities and located in certain neighbourhoods, are able to provide an identity to the neighbourhood. Sharma, (1997) calls the local religious procession as the manifestation of this cohesion. The living quarters, distinctly divided according to the different caste groups, were assigned different set of rules for building, for example, people on the lower caste were prohibited of using tiles on their roofs; instead, their roofing material had to be thatch. Almost all the building materials were sourced locally and built by the local builders and craftsmen. The procedure for building a house was different for each caste with elaborate rituals generally prescribed for higher caste groups. Living closer to the palace was reserved for the elites - the higher caste groups - whose house valued more than a house on a street or a lane, farther from the palace or the city centre (Wright, 1877).

As early as the mid-14 1 century, the Newar rulers established clear guidelines on what a house should look like and its value using religious scripture as a basis for settlement planning. These religious rules of allocating spaces in or outside the city based on one's caste group are a clear and early example of how rules regarding urban space have been used to reflect and reinforce social status. Building scale and visual harmony was emphasized with uniform building designs prescribed for the size and the structure of the building for different castes. Property values for different parts of the cities were standardised. This indicates the expected economic outcomes if the properties were to be sold, i.e. the identification of economic opportunities of the house and land (Wright, 1877). 
The traditional settlements in the city were built usually on the top of the hill, as the main idea was to conserve agricultural land and locate the settlements where cultivation was difficult (Hosken, 1974). But, surprisingly, within these compact settlements, there were plenty of public spaces where people met, markets were held, agricultural products were thrashed and dried, and various festivities were carried out. These activities spilled out from the private spaces of the house to the semi-private spaces of the courtyards to the public spaces such as neighbourhood squares and streets, with very little demarcation between private and public spaces. The relationship between the buildings (both public and private) and the streets and open spaces illustrates not only an understanding of visual requirements but also of the functional and social needs of the population. Similarly, numerous religious festivals that occur throughout the year ${ }^{5}$ are ingenuine expressions of communal living and mass celebrations, relying completely on private or communal funding where whole society comes together. People spent most of their time outside of their houses in squares and courtyards which became meeting and resting places, and where other activities like bathing, drying of produce and family feasts took place (Korn, 1993). These squares were paved like streets (with stone and brick) where various informal trading took place (Wright, 1877). Each neighbourhood opens up into a public square consisting of numerous temples and public rest houses.

\section{Contemporary Architecture}

The contemporary architecture in Kathmandu has its roots in external influences. As early as 1876 Rana rulers travelled to Europe to bring home neoclassical and French renaissance architecture that became the identity of modernity in early years. These trips were the outcomes of the strategic links formed by Rana rulers with British Empire. ${ }^{6}$ Further influences came with growing interest of outside world in the country. In 1951 USAID became the first International agency to sign a bilateral agreement. By 1970s Kathmandu became the destination of the hippie trail or the new Shangrila - the new world space where the Western disenchantment could be contained. The growing importance of the city internationally was accompanied by rapid internal migration that brought diverse ethnic population with disparate material possession. The city's agricultural hinterland became the new material sites for development. Images from the 1960s and 1970s (Hagen 1980) show settlements still clustered around traditional town areas and along major transport routes, whereas between 1971 and 1981, residential land area grew twice (Doebele 1987). Increasing exposure to the outside world fuelled by easy access to international print and visual media influenced the development of so-called modern architecture in the city. The landscape of uniformity and homogeneity in architectural style and design gave way to a collage of styles driven by images of Western modernity.

\footnotetext{
${ }^{5}$ Various festivals are observed in Kathmandu by the local communities such as Bada Dashain, Tihar, Maghe Sankranti : (January), Naga Panchami, Janai Poornima, Pancha Dan Teej/Rishi Panchani, Indrajatra, Ghanta Karna, Buddha Jayanti, Sri Panchami, Maha Shivaratri, Phagu Poornima, Ghodejatra, Indra-Jatra, Chaite Dashain, Nava Varsha, Seto Machchhendranath and Matatirtha Aunsi, Loshar, Shivaratri to name a few.
}

${ }^{6} \mathrm{Nepal}$ avoided Colonial advancement in early $18^{\text {th }}$ Century by bravely fighting the enemy. Later astute Rana rulers befriended British rulers and helped by supplying Gurkha soldiers to contain growing resistance in India. 


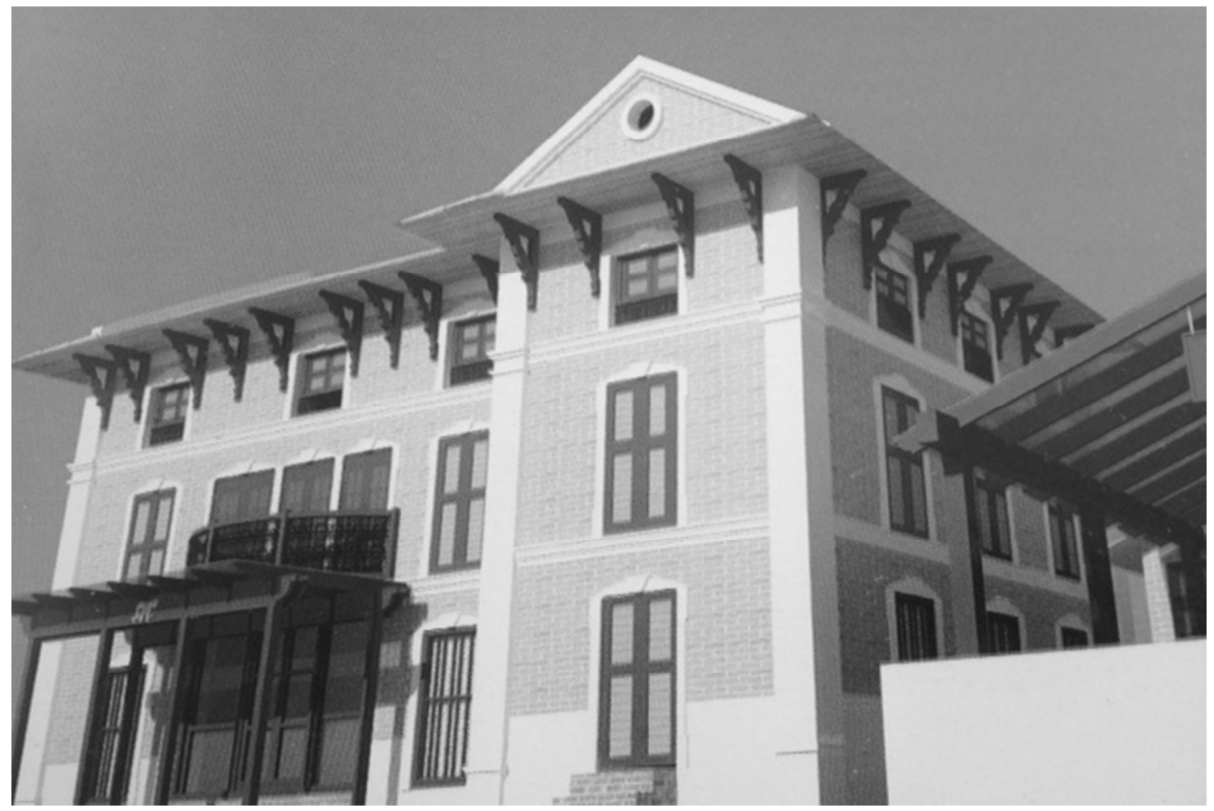

Figure 2: A typical house built during Rana period, Jawalakhel, Kathmandu

Source: Authors

The contemporary urban environment of Kathmandu is dominated by individual piecemeal housing developments. Unlike the houses of the original Newar towns, these houses are usually very different in colour, design and in scale to each other. Introduction of reinforced concrete in the 1950s was instrumental in changing the traditional brick-walled residential houses into bungalow type structures which would start as a single storeyed residence with subsequent addition of floors as the family grew in size and the needs expanded (Shah 2010). More recent houses with multiple storeys had different families living in each floor rented out by the owners. With the rise in land price, housing plots became smaller as the residences rose in height disregarding the by-laws. The evolving landscape was marked by the reinforcement steel bars protruding from [sic] the top slab of buildings, in anticipation of future additions' (Shah, 2010, p. 2).

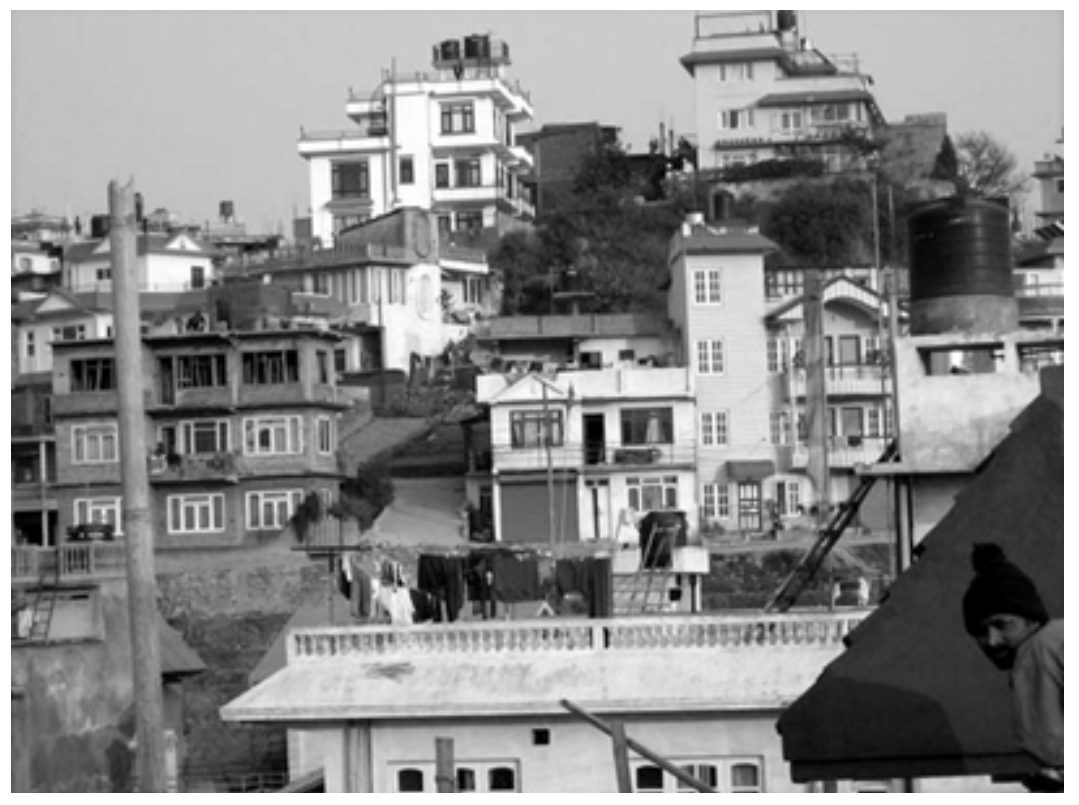

Figure 3: Individually built houses

Source: Authors 
The privately planned residential enclaves in the city emerged since 2000, with the enactment of Apartment Act and deregulation of housing finance. According a conservative estimate there are at least 150 real-estate companies operating in the city creating gated enclaves planned in a grid iron pattern to mimic classic Western suburban neighbourhood designs. Most are developed by the local investors, but lately Chinese, Korean and Indian investors have also entered the market. One of the first housing companies to start planned housing colonies is the Civil Homes Pvt Ltd. Civil Homes is currently undertaking phase seven of housing development on the outskirts of the city. The past six developments have been hugely successful. The Civil Homes website claims it as 'one of the largest planned housing undertakings in the country, it sets new standards of living, amenities and aesthetics'. The developer further claims that the development is specifically and authentically Nepalese:

It is a project undertaken by the Nepalese for the Nepalese people, with conscious efforts made to provide for local conditions, tastes and habits. The exquisitely designed buildings, though contemporary, fit in the Nepalese landscape. Relatively larger plots than most other housing complexes mean reduction in density and truly provides the opportunity of taking in the surrounding natural beauty and vistas. (Civil Homes, 2015)

The Civil Homes Phase III development located at Sunakothi in the southern part of Lalitpur district is one of the biggest housing developments with 200 individual houses in one development. This development was marketed as a place with good views, a peaceful and healthy environment, tree-lined boulevards leading to a central open space for community uses; full security with boundary walls, gates, and guards; an onsite private school, clinic and postal services; as well as a reliable water supply and drainage systems (Civil Housing Program, undated). There are six types of houses depending upon the area of the land and the facilities, but each has some private open space and onsite parking. The prices of these houses at the time of their selling varied from approximately NRs. 3.35 million to 7.75 million (approximately equivalent to $£ 20,563$ to $£ 47,571$, as of July 2015) (Civil Homes, 2009; Civil Housing Program, undated). The developer claims that the housing complex is developed to achieve a greater sense of neighbourhood and to be environmentally friendly by utilising a low density grid street pattern with a hierarchy of road sizes (Civil Housing Program, undated).

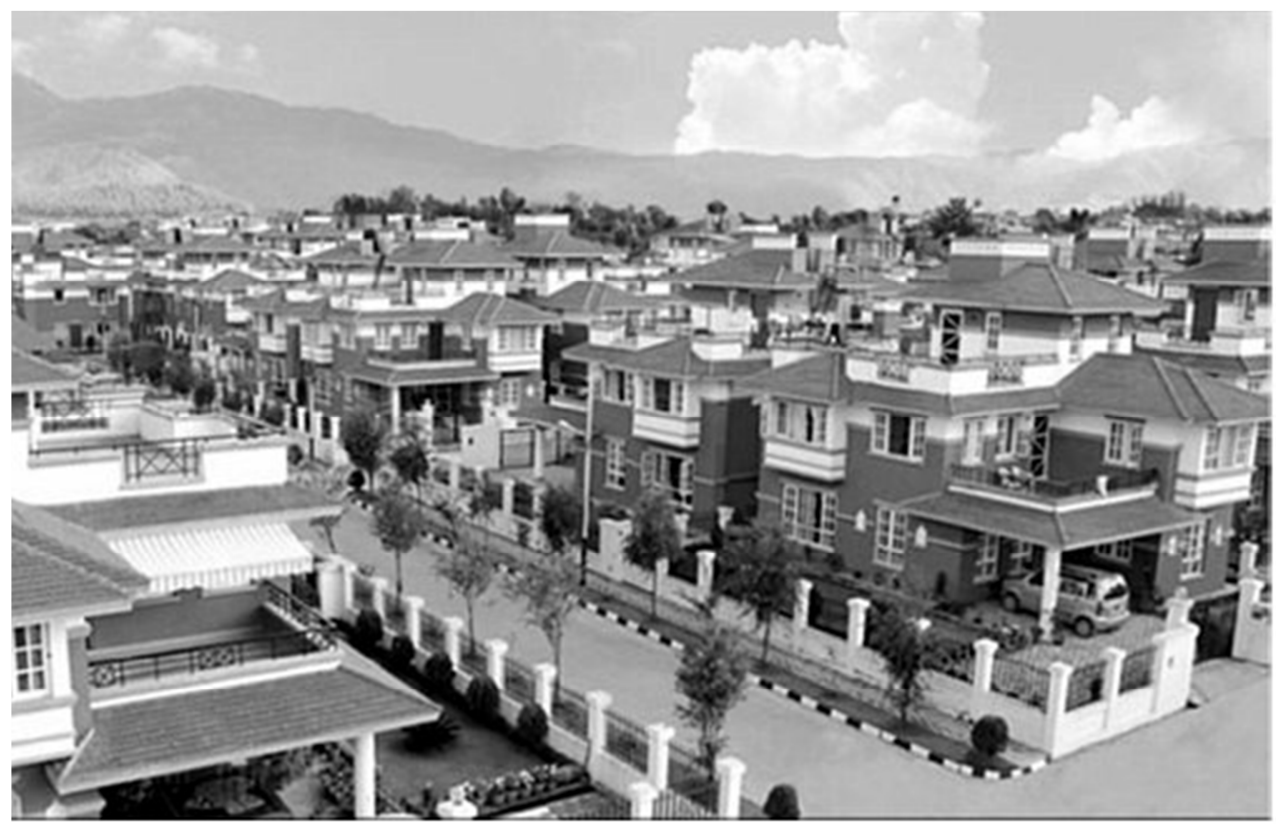

Figure 4: Uniformity in design and aesthetics in houses built by Civil Homes

\section{Source: Civil Homes website, accessed 2009}

Despite the nationalistic marketing blurb, the Civil Homes housing development deliberately imitates the subdivision design of Western gated communities. Entry to the housing is guarded by security personnel and 
special permission from the builder's office was needed simply to visit the site. The researchers observed that development is strictly zoned and there are no commercial activities within the residential areas; while community facilities are allocated to the northeastern section of the complex. Despite six variations in house types, their exteriors varied little as the uniformity bolstered by the use of same material and design element. In contrast to

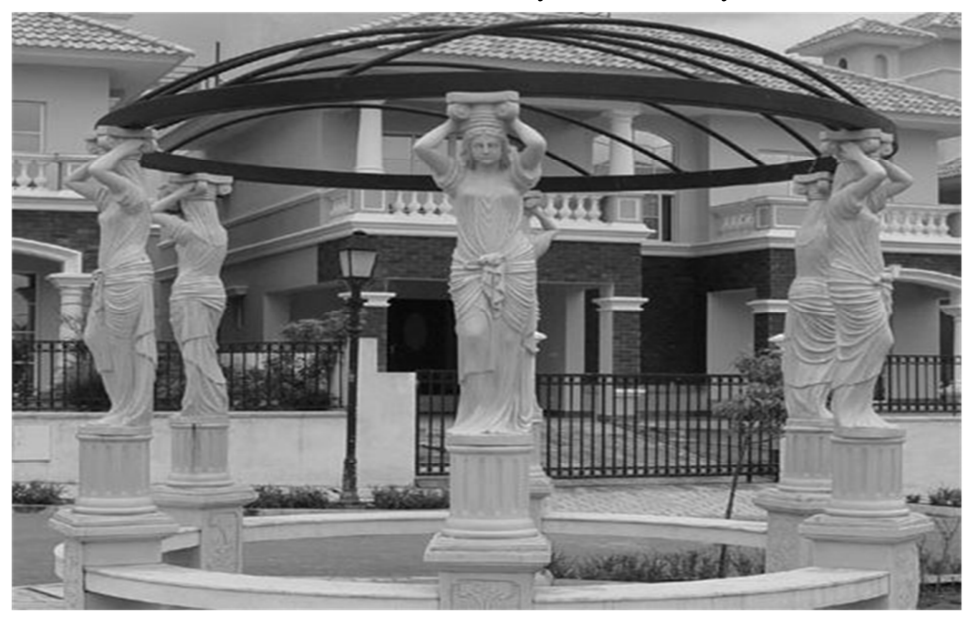

downtown Kathmandu, and even new independently developed areas, both streets and open spaces inside the complex lacked any activity or vibrancy.

Figure 5: Gazebo details in the Terraces, showing the imitation of European sculptures

Another example of modern residential development in Kathmandu is the Terraces also located in Sunakothi. The Terraces, developed by Valley Homes Pvt. Ltd., was marketed as a gated community. The properties were 
sold in 2009-2010, with prices starting at NRs. 12.17 million (approximately equivalent to $£ 74,701$ ) to NRs. 17.56 million (approximately equivalent to $£ 107,786$ as of August 2015). There are 12 different designs, with some potential for customisation to suit specific client needs. These Terraces consist of landscaped gardens, walking and jogging paths, wide open roads, open spaces and a community club with all the modern facilities.

Within the gates, these dwellings present an idealised image of Western home with European neoclassical elements on the exteriors. The Terrace houses are luxurious and expensive in comparison to those in the Civil Homes development. There are no visible references to indigenous architecture or neighbourhood design. In developer-built homes, exterior is often restricted to touch with statues, personal manifestations and identity is rarely seen and households use the interior space to express their fulfilment of cultural expressions. For example, the need for puja room is integral part of every modern house, a puja math made out of cabinet and a space to hold that is indispensable in Nepalese home. If puja room cannot be erected due to space constraints, a domestic Mandir or altar is erected in every home decorated in bright (red/orange cloths) colours and placed in a sacred space. Visits in new apartments show bookshelves and cabinets converted to create these spaces of veneration. Moreover, there are numerous examples of modern Nepalese home adorned with traditional arts and artefacts. This need not be understood as the society's resistance to modernity but a true reflection and sentiments of Nepalese society's use and relationship with space.

More recently, apartment towers have mushroomed across the city, adding a new dimension to residential modernity. Apartments are seen as the ultimate solution to the rapidly growing population. The features such as 'round the clock security system', 'treated water supply', 'gymnasium, sauna \& jacuzzi, swimming pool' are provided including a small temple generally located at the 'site gate'. It is clear that these gated enclosures differ both in social production and social construction from the historic quarters.

\section{Shifting boundaries, social identity and the new modernity}

Kathmandu is by far Robinson's (2006) 'Ordinary city' that is caught between modernity and development. The contemporary Kathmandu is characterised by urbanization, poverty, a fragile governance that is riddled with ethnic conflict and political instability. The city being the biggest urban centre in Nepal experienced huge influx of people from other parts of the country during the civil war between 1996-20077 and, more recently, ethnic violence in Terai (Southern plains). The rural urban migration has had a serious impact on the 'urban structure' due to rapid growth in both housing and economic activities stretching urban boundaries and population (Sengupta and Sharma, 2009). The city's growth and the resultant architecture are underpinned by two different but interconnected movements in contemporary urban development. The physical transformation of the city through sprawl and seizure on one hand and social transformation from caste division to class division on the other, has led to absorption of modernity by the commodity culture and wider community. The meaning and significance of tradition and modernity in everyday life, however continues to create tensions in everyday life.

\section{Sprawl and Seizure}

Kathmandu is no exception to the phenomenon of urban sprawl. It has led to the disappearance of much of rural hinterland and creation of placeless and characterless settlements. The peripheral area in the city is also an uneven territory due to the combined effect of both growing affluence and poverty bolstered by the sprawl and

\footnotetext{
7 A democratic government was established in the country in 1951 after the autocrtatic rule by the Rana Family (1846-1951). However, this new found democracy was again curtailed in 1961 when King Mahendra Shah seized power from the democratic government to rule as the absolute monarch. The "people's movement" in the early 1990s re-established parliamentary democracy in the country, and the role/power of the king was curtailed from that of an absolute monarch to that of a constitutional monarch. As the Kathmandu Valley began to modernise, a privileged few became affluent while life for people in the remote districts of the country became even harder. Growing socio spatial disparities ultimately led to a decade long Maoist guerrilla war in the country until about 2006.
} 
seizure. The former relates to accretion from the efforts of individual land owners and entrepreneurs, whilst the latter reflects an organised effort from private developers and land brokers speculatively amassing large parcels of land in the periphery of the city. Most development is occurring beyond the legal limits of zoning by-laws (Bajracharya et.al, 2015) which in turn, motivates households to move to the city fringes where they would be subjected to lesser building by-laws. The sprawl is also driven by the supply mechanism that prices lower middle class out of the city boundaries. Interestingly there is no legislative framework that prohibits conversion of agricultural land into residential development in Kathmandu. Although prior approval from local municipalities is required, building plans and drawings are assessed in a rather ad hoc basis due to lack of technical and professional expertise. This, coupled with absence of a long term spatial plan has resulted in piecemeal residential development lacking in basic services and infrastructure. As a result, agricultural fields have been converted into housing sites at an alarming speed ${ }^{8}$ resulting in the reduction of peripheral agricultural land from 62 per cent in 1984 to 42 per cent in 2000 (UNEP et al. 2007; Thapa, Murayama and Ale, 2008) with serious environmental consequences. They are the new sites that couldn't be easily policed as laws cannot be enforced.

These sites have also become an easy real estate prey and a profiteering opportunity for canny investors. Thousands of formal and informal land brokers are operating today in buying cheap agricultural land and seizing them until prices are speculatively and artificially raised. This unique blend of sprawl and seizure commodified land and housing market (Sengupta and Sharma, 2009), leading to indiscriminate and even illegal construction of buildings that poses severe health and safety risks let alone possess architectural definition or order. The formal group housing estates are interspersed by the incremental development inadvertently accentuating rather than ameliorating the contest. The peri-urban Kathmandu looks neither planned nor ordered today continually morphing and spreading sequence of spaces that lack distinction. It has bypassed all the norms and nuances, failing to give a coherent shape and form to this development. Gutschow and Kreutzmann (2013) calls it a 'mindset' that is regulated by the market.

\section{Caste to Class}

The apparent architectural (dis)orientation of peri-urban areas owes itself to the incidence of ethnic shift in the population of Kathmandu. The city is hugely diverse with a number of castes and ethnic communities and cultural groups that make up the city. It is the city of Brahamins, Chhettris, Tamangs, Magars, as much as of Madhesis, Tharus and Newars. This ethnic cultural mosaic is seen comprising over 40 per cent of Kathmandu's residents today, with roughly 60 per cent made up of the indigenous Newar population. For a deeply traditional city this could either spell disaster or constitute an epitome of plurality and modernity. Tiwari (2001) argues that the loss of cultural heritage in Kathmandu may be ascribed to lack of understanding of its importance and relevance by the immigrants and traditional inhabitants alike. The house types and settlement patterns of the people who immigrated show lack of a closely knit society with a high social order (Shrestha, 1981) while they sought to create their own urban enclaves. In the historical core ancestral dwellings are extended to create more space, increasing to accommodate expanding family members. Attractive portrayal of modernity pushed wealthy dwellers to move out of the historic core. Those who remained, subdivided their homes in apparent vertical expansion leading to narrow blocks jutting out of the roofline.

Within each ethnicity, a hierarchy of castes is embedded, its origin dating back a thousand year. The layout of the traditional city was largely defined by the caste since mid-14th century (courtesy the Medieval king Jayasthiti Malla). Following the Hindu order, each caste was assigned its own customs in relation to dwellings, dress and ornaments and jobs. Lower castes such as Kasais and Podes were not allowed to have houses roofed with tiles. The occupational castes were distributed generally throughout the city, except for the central area, which housed the palace and the main Brahman/priest cluster. While the structural differentiation imposed by caste system remained throughout the centuries, the religious framework unified the population in the socio-political

8 According to a recent study (Bajracharya et al. 2015), the built-up area in the municipalities grew from $38 \mathrm{Km}^{2}$ to $999 \mathrm{Km}^{2}$ between 1990 and 2012, an almost threefold increase. 
framework (Bhattarai, 2004). Caste defined and guided all the religious ceremonies, rituals, marriage, social interactions etc. In the twentieth century however, the importance of 'caste' and the context of caste-based physical planning has understandably diminished. With this, the caste-based management of community infrastructure, function and usage of space has disappeared.

Civil Homes (discussed above) for example is a complete self-contained constellation of residential buildings. The plans, elevations and the layout of the development appears borrowed, at best a mimicry of western middle/upper-class imaginaries which are unfamiliar and distant to indigenous culture. Architecturally, individual houses and terraces rooted in post-modern architectural pastiche, or adorned with classical and baroque details reflect an ostensibly universal nature of these projects are devoid of Nepalese architectural identity. They clearly make the owners 'privileged', 'secured' and 'special' with a guardhouse, 24 hours water and electricity supply, uniformed security men. But their Nepaleseness remains questionable. Within these gated enclaves, other forms of homogeneity based on income, class and lifestyle etc. are becoming more apparent. They represent a particular 'group' whose identity cannot be variegated in terms of caste or ethnicity.

The transition from caste to class division in the society has been further complicated by ethnicity, which is increasingly gaining prominence in political discourse. Although Kathmandu's ethnic division shows an increasing tendency of diversification rather than enduring concentration, the peripheral areas such as Koteshwor, Gangabu and Kapan are ethnically dominated. Ethnicity has also been one of the most politically divisive dimensions in the country. It has been a double sword with its links with both 'caste' and 'class' disparity in the society. For instance, an ethnic population could belong to a lower caste which is also economically deprived making it one of the most abused tools in the political arena. On the other hand, planned housing as second home or future investment and creation of expensive enclaves of housing and commercial complexes/departmental stores in the city has led to spatial division in rich and poor neighbourhood (Shrestha, 2010, Kobayashi, 2006). The duality in 'thinking' (nativeness and ethnicity) and 'practice' (modernity and westernized) has led to poorly defined and articulated neighbourhoods that fuel the disorientation as far as residential architecture is concerned.

\section{Tradition vs Modernity.}


The embodied urban change in Kathmandu transcends beyond the dichotomy of tradition vs modernity and into the realm of identity of its urbanism it now beholds. The discursive nature of the city building process and the dubious identity makes it a city in transition. Every layer of new brick that is added today searches for a new urbanism. Despite being one of the most impoverished nations in the world, Kathmandu exhibits real estate traits similar to any second tier city in United Kingdom or Australia. A typical dwelling cost ranges from NRs 10 million to NRs 25 million (roughly $£ 0.1$ to $£ 0.25$ million) in the newly developing housing estates (see, housingnepal.com). One may wonder who the consumers and new residents of these housing estates are. Some of them are the local indigenous people who have prospered over the years and want to set themselves free from tradition. But a substantial number of them are from other parts of the country or people living elsewhere either due to economic compulsion or very rarely, by choice. Sengupta and Sharma (2009, p.36) observed that this was mainly targeted to the large influx of wealthy migrants concerned with security situation in various parts of the country, bringing with them capital to invest in land and housing in Kathmandu. A significant proportion of the supply is now consumed by the Non-resident Nepalese (NRN) with the remittance money that now stands as one of the biggest revenue generators for Nepalese economy' influencing not only household consumption and investment patterns, but overall economic structure and dynamics' (ADB, 2014).

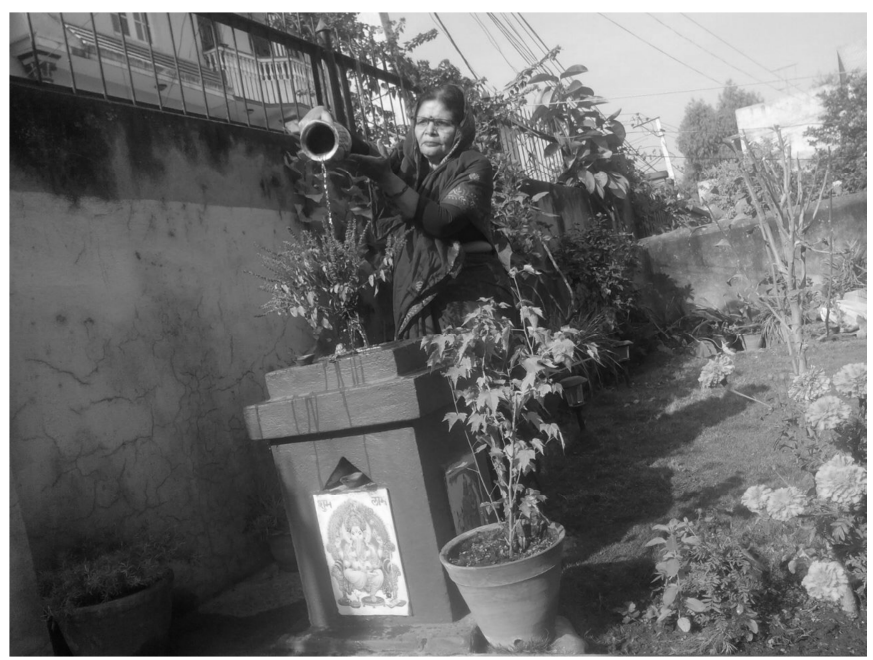

Figure 6: A Tulsi (Basel) plant in a modern Nepalese home Source: Authors

The cultural distortion associates commodification of land and housing with the societal status accompanied by a quest for modernity. In the process indigenous culture and builtform has been devalued, although as Nelson (2010) argues it lives on in the mindset of occupiers of new colonies and apartments as they start to look for ways to reintroduce the old culture in new spaces. Common inside the gated development are the shoots of traditional living and social interactions. It can be argued that the sprawling city growth and its modernist imaginaries is held back due to what Robinson (2006) calls 'anxiety' arising from reliance on borrowed culture, betrayal of local cultural forms and economic realities. For instance the Tulsi (basil) Math, best characterizes the continuity of tradition within modern homes. Part of Hindu culture of planting, a Tulsi plant at home (either in the courtyard, terrace garden or in ubiquitous Verandahs) symbolises purification, has medicinal use and used in religious veneration and even given to the dying persons to purify their soul. The multiple manifestation of single plant in so many different forms of Sanskaras, can never be realised with its replacement by an orchid plant that so many modern homes in Kathmandu have come to be adorned with. A dubious compromise then happens in the form of a blooming orchid right next to a basil plant. These cultural practices are not necessarily just beliefs and outlooks or symbolic acts, but these are rituals in which a discourse is embedded. While these practices do not directly represent the disintegration of the modernity, they explicitly take up the other aspect of its thesis: the failure of the new order to emerge and replace the tradition. Explained differently the homogenizing effects of buildings and spaces go on to produce a response in the (re)invention of tradition. 
Another classic example would be the use of traditional stone water taps locally called Dhunge dharas ${ }^{9}$, which were not only the source of water but also provided space for social interaction and various cultural practices. They appeared from the vertical wall, often with a shrine or idols of gods and goddesses engraved to it, which are today at the verge of drying up. Some of them have been removed to accommodate new development. Whilst with development of municipal piped water, the utilitarian value of these traditional watersprouts has been obscured, their aesthetic dimension and their embodiment of Hindu references of gods and goddesses has remained intact. Thus their removal is largely about 'appropriating the modernity which is a cosmopolitan phenomenon' (Robinson, 2006, p.148). Like these watersprouts- builtform, design and urban spaces -are changing in the valley. A wider circulation of materialistic culture coupled with ideological distortion has created a new order of uncertainties dissolving intimate social forms and community relationships, to be replaced by sterile isolation and social fragmentation.

On the other hand, society's relationship to land harks back to the tradition and rurality left behind by migrants. By and large, the cultural production of gated and self-contained new residential enclaves in Kathmandu has been the modern manifestation of Western suburban culture. Perhaps unsurprisingly, several typical morphological features of Western suburban development are recognizable in the layout of these modern enclaves including Civil Homes. This observation however ignores a crucial detail that relates to a small parcel of land provided in the curtilages of nearly all homes. In our visits we have witnessed instances of developerprovided front lawns being converted into de facto vegetable gardens. These apparently are not a subsistence related activities but rather, an intense desire to introduce a slice of rurality. Such symbolism is profoundly significant in the debate of tradition vs. modernity. Whilst, we would not underestimate the relevance of the dichotomy between town and country in defining modernity especially in European cities, the same argument does not fit a deeply traditional city or society, given, whilst stressing the element of modernity, these enclaves in Kathmandu are both urban and rural simultaneously. The urban and rural are only conceptually different, but come together in everyday social life.

Changes, both coercive or voluntary through the impact of globalisation and technology have affected both architecture and lifestyles in Kathmandu in a visible way but they have done little to change the way society uses space or desires to do so. Liechty's (2010) extensive ethnographic study of middle class culture in Kathmandu suggests how the city has engaged, produced and reproduced global cultural processes, however the conditions under which they takes place remains external. The city is neither qualitatively different from its non-urban spaces nor from its 'primitive' form given the intense traditional values and practices still dictating the way people shape and reshape buildings and spaces. There are traditional practices and system that have held their values in the modern times. The Guthi system ${ }^{10}$ for instance is an example of an indigenous system that exhibits modern attributes despite being introduced some six hundred years ago. This brings us back to Mumford's (1962) emphasis on organic relationship between people and their living spaces in cities. The physical design of cities and their economic and technological functions are secondary to their relationship to the natural environment and to the spiritual values of human community. On this basis we contend that the dialectical relationship between cultural imaginaries and the city development may appear contradictory today but it is far from being a finished 'project'. Instead the relationship is still evolving and reshaping with every day activities and any social-scientific analysis remains just a conceptual starting point.

It is rare in the Nepalese society to engage in critical analysis of the buildings, spaces or its architecture. The stylistic delineation of Nepalese architecture was initiated and idealized in literature by passionate researchers from the West (mainly Germany) such as Gustchow and Kreugtmann (2010), Slusser (1982). Levy's (1992)

\footnotetext{
9 The traceable history of Dhunge Dharas goes back to $550 \mathrm{AD}$ when Bharavi, the grandson of King Mandeva from Lichhavi period built the first Dhunge Dhara in Hadigaon (Pradhan, 1990). There are 117 Dhunge Dharas in Kathmandu and another 40 in Patan.

10 The Guthi is an association formed by groups of people or members of a family based on caste, patrilineal grouping or territorial aspects created to generate financial and social capital from collective land ownership. It helped to finance regular maintenance of a wide range of heritage items and monuments alongwith the observance of cultural rituals and festivals practiced by local people.
} 
archaic city, Slusser's (1982) Mandala city suggest that medieval Nepal exploited opportunity to place traditional architecture strategically to construct its identity. The contemporary architecture, on that basis, would thus, go through the natural scrutiny on its contribution to identity the city has acquired and/ or its continuity. Kathmandu has thus become the fertile ground for the debate on style and its complexity, contention and traditional ideology, and finally deviation from it. Architectural style as an evaluative category to define the nativeness and modernity appears at this juncture, still inadequate to represent the discursive nature of architecture or cultural production, which is neither linear nor tangible. The connection between the city and native residents is deep and suggests approaching modernity through different kinds of methodological approaches, such as the analysis of Nepalese attitudes toward the organization of space in order to understand how new spaces of modernity are being shaped. Shoots of new methodology have been witnessed in revitalisation projects in Siddhakali, Thimi that combines tradition with modern within historic old core as the new generation of use of architecture in cultural production. Likewise new breed of Nepalese architects are combining tradition with modernity (Mahato, 2010). However, there is very little in terms of introducing a new residential architectural discourse that would sustain outside these individual and piecemeal efforts. In this sense the question where tradition ends and modernity begins becomes increasingly irrelevant.

\section{Conclusion}

Octavio Paz (1974, p23) claimed, 'modernity is an exclusively Western concept that has no equivalent in other civilizations'. This paper develops this claim in articulating how emerging architecture in Kathmandu exists within the blurred lines of modernity and tradition. As an analytical category the paper uses both emic etic representations of everyday life to capture the elusive traces of traditions in new modern residential architecture that could potentially lead to a new form of cultural production. Not only has it become an ongoing, potent symbol of engagement with the past, but within these symbols are also found traditional practices and ways of life that have evolved over many centuries. The traditional architecture in Kathmandu, shaped by well-structured societal norms and religious practices, has, in turn, helped preserve these very norms and practices to give a cultural continuity. Commenting on early signs of ruptures and discontinuity in traditional practice Shrestha (1981) questions, how much of these architectural treasures could be preserved in the transition to modernity. Nearly four decades later, as the transition to modernity intensifies, the question becomes even more pertinent.

The emerging architectural trend in Kathmandu is a result of complex outcome of combination of changes taking place under the conditions both internal and external or atraditional. Physical transformation triggered by sprawl and seizure and societal transition from caste to class manifest in architectural modernity. The advent of modernity, however, grounded in historic timings, subscribes to different reference points. Modernity in residential architecture has been shaped during the decades globalisation flourished with a powerful architectural vision laden with western ideals and aesthetics. Private developers have become the torchbearers to promote this vision, which has been well received by the migrant communities, increasingly disoriented by the domestic violence, ethnic diversity and rapid transformation in the society. However, a parallel trend of linking back to tradition is evident in disparate forms across many enclaves of modern distinction.

Kathmandu's gradual expansion and the tension between the city's historic centre and peripheries are increasingly shaping the city's identity. Neither this tension nor the architectural legacy is articulated by media or found in public discourse or political agenda. A formidable civic activism emerged in recent years for high profile cases $^{11}$ but they have been short-lived and confined to institutional buildings. It is surprising that the three decades of civil war has been brimmed with nationality and nationhood, while the same consciousness is not evident in new architectural forms and patterns. Triangular pediments and French Windows travelled to the country from Europe, so did the use of sandstones, marble stones or stained glasses. These practices have steadily grown to undermine the value of historic enclaves as centres of tradition, identity and nationhood. It is a tragic paradox that the contemporary architecture in Kathmandu turns its back on the very legacy that gave the city its identity. The residential architecture today stands disoriented, lost in the transition.

\footnotetext{
${ }^{11}$ Examples include resistance to add extra floors to the Zonal Office next to Rani Pokhari and Louis Kahn's Agriculture Bank building with partial success.
} 


\section{REFERENCES}

Aranha, J. L. (1991). 'A comparisons of Traditional settlements in Nepal and Bali'. Traditional Dwellings and Settlements Review, Vol. 11, pp. 35-47.

Asian Development Bank (2014). 'Effects of Migration and Remittance Income on Nepal's Agriculture Yield'. ADB South Asia Working Paper series, No.27, July, ADB: Manila.

Bajracharya, A. et.al. (2015). Planning for affordable housing during densification in Kathmandu Lessons from four settlements, Working Paper, International Institute for Environment and Development (IIED): London.

Bhattarai, H. P. (2004). 'Cultural Diversity and Pluralism in Nepal: Emerging Issues and the Search for a New Paradigm'. Contributions to Nepalese Studies, 31(2): 393-340.

Civil Homes. (2009). 'Introduction'. Available at: http://www.civilhomes.com/intro.htm. (Accessed 24 February 2009)

Civil Homes. (2015). 'The Company'. Available at: http://civilhomes.com/housing-company-in-nepal/ (Accessed 24 July 2015).

Civil Housing Program (undated). Civil Homes-Phase 3, Civil Homes Marketing and Project Office.

Department of Housing and Urban Development, Asian Development Bank, et al. (1991). Kathmandu Valley Urban Development Plans and Programs. Kathmandu, HFA, PPK, CEMAT.

Doebele, W. (1987). 'Intervening in the Informal Urban Land Supply: Neglected Opportunities'. Paper prepared for USAID.

Gutschow N and Kreutzmann, H (2013). Mapping the Kathmandu Valley with Aerial Photographs by Erwin Schneider. Kathmandu: Himal Books

Haaland, A. (1982). Bhaktapur- A Town Changing. Kathmandu, Bhaktapur Development Project.

Hagen, T. (1980). Nepal. New Delhi, India: Oxford and IBH Publishing Co.

Hosken, F. P. (1974). The Kathmandu Valley Towns: A Record of Life and Change in Nepal. New York, Weatherhill.

International Centre for Integrated Mountain Development (ICIMOD), United Nations Environment Programme (UNEP), et al. (2007). Kathmandu Valley Environment Outlook. Kathmandu, International Centre for Integrated Mountain Development (ICIMOD).

Kirkpatrick, W (1811). An Account of the Kingdom of Nepaul, Being the Substance of Observations Made During a Mission to that Country, in the Year 1793. London: William Miller, Albermarley-Street

Kobayashi, M. (2006). Social change in Kathmandu related with globalisation and liberalisation - Potential of new life style and domestic market. Planning Journal of Tokyo University, 44(1), pp. 27-38.

Korn, W. (1993). The Traditional Architecture of the Kathmandu Valley. Kathmandu, Ratna Pustak Bhandar. 
KTM2Day (2014). 'Apartment builders gear down and wait for market revival'. Feb 9. Available at: http://www.ktm2day.com/2014/02/09/apartment-builders-gear-down-and-wait-for-market-revivall. (Accessed 26 $6^{\text {th }}$ July 2015)

Levy, Robbert I. (1992). Mesocosm: Hinduism and organisation of a traditional Newar city in Nepal

Liechty, M. (2010). Out Here in Kathmandu: Modernity on the Global Periphery, Kathmandu: Martin Chautari Press.

Mand, H. (2013). Asia: identity, architecture and modernity, The Journal of Architecture, Volume 18, No.1, pp. 59-78.

Mahato, $R$ (2010). A new generation of Nepali architects is striking a balance between heritage and modernity available at http://nepalitimes.com/news.php?id=17538\#.ViKdzMuFPIV

(Accessed 15 October 2015)

Müller, U. (1981). Thimi: Social and Economic Studies on a Newar Settlement in the Kathmandu Valley. Giessen, Selbstverlag des Geographischen Instituts der Justus Liebig-Universitat Giessen.

Mumford, L. (1938). The Culture of Cities. New York: Harcourt Brace.

Mumford, L. (1961). The City in History: Its Origins, its transformations and its prospects. New York: Harcourt Brace \& World Inc.

Nelson, A. (2011). 'No Horn Please: Self governance and sociality in a Kathmandu Housing Colony'. In Anjaria, Jonathan S. and McFarlane, C. (Eds.) Urban Navigations: Politics, Space and the city in South Asia, pp. 213238, India: Routledge:.

Northey, W. B. and Morris J (1928). The Gurkhas: Their Manners, Customs and Country, India: Asian Educational Services

Pant, M. (2002). A Study on the Spatial Formation of Kathmandu Valley Towns- The Case of Thimi. Unpublished thesis $\mathrm{PhD}$, Kyoto University.

Paz, Octavio (1974). The Children of the Mire: Modern Poetry from Romanticism to the AvantGarde. Cambridge: Harvard University Press.

Pradhan, R. (1990). 'Dhunge Dhara: A case study of the three cities of Kathmandu Valley'. Ancient Nepal: Jurnal of the Department of Archaeology, Number 116-118, pp. 10-16.

Robinson, J. (2006). Ordinary Cities: Between modernity and development. London: Routledge.

Sengupta, U. and Sharma, S. (2009). 'No longer Sukumbasis: Challenges in grassroots-led squatter resettlement program in Kathmandu with special reference to Kirtipur Housing Project'. Habitat International, Vol. 33, No. 1, pp. 33-44.

Shah, B. (2010). 'A Brief Overview of Incremental Housing Construction in Kathmandu Valley, Nepal'. Global Consortium for Incremental Housing. Available at: 
http://web.mit.edu/incrementalhousing/articlesPhotographs/nepalKarthmanduValley.html (Accessed 26th July 2015).

Sharma, P. R. (1997). Kul, Bhumi Ra Rajya: Nepal Upatyakako Purba-madhyakalik Samajik Adhdyan (in Nepali). Kathmandu, CNAS.

Shrestha, M. (1981). 'Nepal's Traditional Settlement: Pattern and Architecture'. Journal of Cultural Geography, Vol.1, Issue 2. pp. 26-43.

Shrestha, B K (2010), Housing provision in the Kathmandu Valley: Public agency and private sector initiation, Urbani izziv, Volume 21, no. 2

Slusser, M. (1982). Nepal Mandala: A Cultural Study of the Kathmandu Valley. Princeton, NJ, Princeton University Press.

Thapa, R., Murayama, Y. And Ale, S. (2008), Kathmandu, Cities, Vol. 25, pp. 45-57.

Tiwari, S. R. (2008). 'City Space and Life Then, 150 Years Ago: A Presentation of Concept and Realities'. Vedic Udbodhan. Available http://www.kailashkut.com/City\%20Space\%20and\%20Life\%20150\%20years\%20ago.pdf. (Accessed 21 October 2008)

Tiwari, S. R. (2001). 'Heritage Conservation'. City Diagnostic Report for city Development strategy: Kathmandu Metropolitan city, Report, pp.219-254, Kathmandu Metropolitan city and the World Bank.

Valley Homes. (2009). 'House Plans'. Available at: http://www.valleyhomes.com.np/houseplan.html. (Accessed 24 February 2009).

Valley Homes Pvt. Ltd. (undated). Welcome to Luxury, Valley Homes Pvt. Ltd.

Wright, D. (1877). History of Nepal. London, Cambridge, Cambridge University Press. 